\title{
The Politics of Gendered Spatializations: A Study of Cityscapes in Manu Joseph's Novels
}

\author{
Parvathi M.S. \\ Research Scholar, Department of English Literature, The English and Foreign Languages \\ University, Hyderabad, E-mail: msparvathi1994@gmail.com, ORCID id: oooo-ooo2-9191-
} 5999

\begin{abstract}
Burton Pike (1981) terms the cityscapes represented in literature as word-cities whose depiction captures the spatial significance evoked by the city-image and simultaneously, articulates the social psychology of its inhabitants (pp. 243). This intertwining of the social and the spatial animates the concept of spatiality, which informs the positionality of urban subjects, (be it the verticality of the city or the horizonality of the landscape) and determines their standpoint (Keith and Pile, 1993). The spatial politics underlying cityscapes, thus, determine the modes of social production of sexed corporeality. In turn, the body as a cultural product modifies and reinscribes the urban landscape according to its changing demographic needs. The dialectic relationship between the city and the bodies embedded in them orient familial, social, and sexual relations and inform the discursive practices underlying the division of urban spaces into public and private domains. The geographical and social positioning of the bodies within the paradigm of the public/private binary regulates the process of individuation of the bodies into subjects. The distinction between the public and the private is deeply rooted in spatial practices that isolate a private sphere of domestic, embodied activity from the putatively disembodied political, public sphere. Historically, women have been treated as private and embodied and the politics of the demarcated spaces are employed to control and limit women's mobility. This gendered politics underlying the situating practices apropos public and private spaces inform the representations of space in literary texts. Manu Joseph's novels, Serious Men (2010) and The Illicit Happiness of Other People (2012), are situated in the word-cities of Mumbai and Chennai respectively whose urban spaces are structured by such spatial practices underlying the politics of location. The paper attempts to problematize the nature of gendered spatializations informing the location of characters in Serious Men and The Illicit Happiness of Other People.
\end{abstract}

Keywords: spatiality, space, gender, positionality, representations of space, public/private binary, spatialization, location, cityscapes

\section{Gendering Spaces}

The conceptual framework of spatiality involves the displacement and transgression of the traditional notions of time, space, history, and progress and privileges the spatial structures underlying the configuration of cultural and libidinal economies and linguistic forms (Jameson, 1981). Jameson's spatial imagination delineates spatiality as emerging from the dialectic between the spatial and the social, where space is structured by material realities and cultural codes (involving familially ordered sexual desires and regimes of discipline) which, in turn, produce the bodies of subjects (Grosz, 1994). As bell hooks (1989) argues, our positioning in space or our place informs our perspective and enables us to resist dominant discourses of power: "As a radical

(c) AesthetixMS 2020. This Open Access article is published under a Creative Commons Attribution Non-Commercial 4.0 International License (http://creativecommons.org/licenses/by-nc/4.o/), which permits non-commercial re-use, distribution, and reproduction in any medium, provided the original work is properly cited. For citation use the DOI. For commercial re-use, please contact editor@rupkatha.com. 
standpoint, perspective, position, 'the politics of location' necessarily calls those of us who would participate in the formation of counter-hegemonic cultural practice to identify the spaces where we begin the process of re-vision" (pp. 145). One of the social relations animating these spaces of re-vision is gender, which is entwined with the politics of location in the psychical and social inscription of bodies. Feminist geographers such as Doreen Massey (1994), Nancy Duncan (1996), Linda McDowell (1999), and Elizabeth Grosz (1994) identify the modes of articulation of space and gender in the formation of subject positions, maintaining that space structures and is structured by gender relations. Jane Rendell (2000) expounds that the biological sex of the subjects occupying spaces enables their determination as sexed. However, certain spaces are identified as gendered on account of the gender signified by the activities occurring in them. Representations of spaces in literature are informed by this politics of location which genders spaces. The paper attempts to identify the structuring practices that inform the gendering of urban spaces in Manu Joseph's novels, Serious Men (2010) and The Illicit Happiness of Other People (2012).

\section{The Ideology of Separate Spheres}

A pervasive mode of gendering spaces is the paradigm of the separate spheres which, as Jane Rendell (2000) remarks, is an "oppositional and hierarchical system consisting of a dominant public male realm of production and a subordinate private female one of reproduction" (pp. 103). The separation of spaces into public and private domains typifies Western intellectual history's telos privileging disembodiment, manifested in Plato's conception of the soul and in the Cartesian privileging of incorporeal reason, which, subsequently, delegitimizes the body. The delegitimizing of the body is, according to Iris Marion Young (1987), embedded in liberal political theory which relies on "an opposition between public and private dimensions of human life, which corresponds to an opposition between reason on the one hand and the body, affectivity, and desire on the other" (pp. 63). Immanuel Kant's epistemology further imbricates the ideology of public/private binary within the mind/body dualism and locates reason in the public sphere (Duncan, 1996). Kant's disembodied Enlightenment individual is defined by his willingness to use reason in a public space and is embedded in structures of masculinity. The materiality of women's bodies forecloses their positioning in the public space and instead relegates them to the private space (which is structured by feelings rather than by the universal principle of reason and knowledge). The mind/body dualism and its accompanying public/private binary simultaneously enable the exclusion of women from the public space and from domains of science and knowledge. This oppositional and hierarchical system promotes the separation of the dominant public male realm of production from the subordinate female private sphere of reproduction.

The spatial schema of the separate public and private domains is ostensibly demonstrated in the gendered geographies of Serious Men and The Illicit Happiness of Other People. The spatialities of the protagonists, Ayyan Mani and Ousep Chacko involve public spaces, including their workspaces, streets, and public parks. This spatialization extends to most of the male characters positioned either at the Institute (as in Serious Men) or on their rickety scooters, navigating their way from their workplaces to their homes (as in Illicit Happiness). However, the women characters in Serious Men are mostly the female inhabitants of the BMC chawl which include Ayyan Man's uneducated wife, Oja or the innumerable "hungry housewives, whose saris slipped off their blouses as they innocently enquired in how many colours the vacuum cleaners came...upon the incandescent sight of the Eureka Forbes salesman” (pp. 83). Though the narrative of Illicit Happiness is situated in Chennai, it emulates the spatial practices of Serious Men apropos the positioning of its women. The censorious, middle-class women residing in the apartments in 
Balaji Lane are limited to the domestic spaces, like their uneducated, hungry counterparts in Serious Men. Mariamma, in Illicit Happiness is conspicuously frustrated by her subject position, and resents Ousep for his responsibility in triggering their exile from Kerala and for her subsequent domestic confinement. (She is depicted as venting at "her bare walls all her reasonable grudges... with a ferocity that makes her head tremble and her eyes look interested" (pp. 51)). The spatializations of Mariamma and Oja are embedded in discursive practices that construct the private spaces as feminine.

\section{The Politics of Vision}

The practices of spatial organization informing the representations of spaces in these novels produce and are, in turn, productive of ordering of sexual difference. Shirley Ardener (1993) illustrates this mutually constitutive association through her concept of social maps:

"Societies have generated their own rules, culturally determined, for making boundaries on the ground and have divided the social into spheres, levels and territories with invisible fences and platforms to be scaled by abstract ladders and crossed by intangible bridges with much trepidation or exultation as on a plank over a raging torrent" (pp. 126).

One of the culturally determined rules regulating the location of women in literature is what Griselda Pollock (1988) terms as "the politics of vision" (similar to what Laura Mulvey formulates as the male gaze in movies) in which the social ordering of the gaze operates to secure a particular organization of sexual difference (pp. 62). The opening paragraphs of Serious Men position women in public spaces within the matrix of heterosexual gaze where women are the objects of visual consumption for the looking male subjects: "Solitary young women in good shoes walked hastily, as if they were fleeing from the fate of looking like their mothers. Their proud breasts bounced, soft thighs shuddered at every step... He imagined they were all in the ecstasy of being seduced by him" (pp. 1). The politics of male gaze underlying the construction of public spaces operate in situating Oparna Goushmoulik in her workplace:

"Oparna Gaushmaulik was still not granted the peace of anonymity, but she was now an insider. Those cold gazes when she went down the corridors in the wooden beat of her low heels, the number of old scholars who wanted to show her the right path while staring at her breasts, and their wives, some of them, who arrived to have an accidental meeting with her and see for themselves the talk of the Professors' Quarters-those days were over. Only minor assaults remained. Some wiry postdoctoral students still gaped at her with infatuated eyes, an ancient professor of Number Theory who inhabited the corridors these days waylaid her and showed her his nature poems" (pp. 32 ).

The schema of the gaze which embeds Oparna as an object permeates other instances where the female characters are occasionally situated in public spaces. Mythili, the teenaged neighbor in Illicit Happiness is also evoked in traditionalist modes where she is positioned mostly as the object within the schema of the gaze: "Her balcony has become a shrine that pulls boys and men from faraway places. They come to strut up and down the lane for her... The times she appears on the balcony, it is as if a circus bell has rung and the clowns below must begin to perform" (pp. 118). The structuring practices of the geographies of Oparna and Mythili corroborate that the situation of women in public spaces is contingent on their objectification. Their objectification perpetrates the literary construction of cities as masculine domains where 
men are subjects and women are the delegitimized objects within the hierarchy of the heterosexual, male gaze.

\section{The City as Metaphor}

The construction of literary cities in modes of masculinity ossifies the gendering of spaces. These gendering practices position women in domestic settings, which are traditionally conceptualized as places of privacy and security. However, the chawls and apartments that constitute most of the domestic spaces in these novels subvert the ideology of domesticity: "In some rooms here, over a dozen lived. So the newly-weds lived on the illegal wooden lofts with the unspoken assurance that the rest of the family would not look up" (Joseph 2010:8). The lack of privacy characteristic of these domestic settings is emblematic of the postmodern formulation of urbanscapes where synthetic public sites for shopping and recreation are juxtaposed with the carceral spaces of the poor. The biopolitical governmentality administering these carceral spaces by means of a securityparanoid gaze reducing the poor to their bodies and enclosing them within the compounds (Keith and Pile, 1993). The conception of domestic spaces as sites of incarceration crystallizes the anxiety of living in postmodern hyperreal cities. Though the male characters are mostly positioned in the public spaces of the city, they do not celebrate their positioning in the mode of Walter Benjamin's flâneur (Benjamin's flâneur epitomizes the intertwining of experience, situated knowledge, and subject position). The literary cities of Ayyan Mani and Ousep are sites of consolidation of power and of contextualizing the internalization of social rules. The internalization of their social inferiority generates persistent awareness of their subject positions (either as a Dailt, in an overwhelmingly upper-caste Mumbai or as an unemployed alcoholic in the middle-class settlements of Chennai), which preclude their sense of belonging in the city. The sense of unease experienced by the city dwellers is encapsulated in Burton Pike's (1981) conception of "word-city" which articulates how literary cities inform the social psychology of its inhabitants (pp. 398). However, this unease does not transcribe into the perception of cityscapes as monolithic environments that do not nurture the development of human nature. This perception legitimizes Enlightenment notions of humanism which authorizes the centrality of the human (male) subject which, in turn, reifies the logic of Enlightenment rationality informing the gendering of real spaces and of word-cities. Instead, these word-cities ought to be perceived as toponymical rather than topographical constructions which are generated from the positional and fragmentary perceptions of the characters. These positional perceptions enable the formulation of multiple geographies that resist the hegemony of the public/private binary.

\section{Conclusion}

The methodological assumptions underlying spatializations involve privileging the dialectic between the spatial and the social, where space structures and is, in turn, structured by gender relations. The paradigm of the separate public and private spheres typifies this dialectic which encompasses a dominant public male realm of production and a subordinate private female space of reproduction. This gendering of spaces is animated by the mind/body dualism in Western epistemology which, in turn, generates the public/private binary. The ideology of gendered spaces enables the exclusion of women from the public space and from fields of science and knowledge. The novels by Manu Joseph are embedded in this ideology of separate spheres where the geographies of the male characters extend to include workspaces, streets, and sites of recreation. Meanwhile, the women are mostly positioned in private spaces which are discursively structured as feminine. In these novels, the occasional situation of women in public spaces does not contest the hegemony of the public/private binary. The representations of women characters in 
5 | The Politics of Gendered Spatializations: A Study of Cityscapes in Manu Joseph's Novels

workspaces and on the streets manifest in their objectification by the heterosexual, male gaze. The hegemonic representations of gendered spaces reify the construction of literary cities as masculine geographies. However, the conceptualization of cities as masculine enables Enlightenment notions of humanism which privileges the human (male) subject. Instead, the representation of the cities ought to be informed by the politics of location which generates positional and fragmentary perceptions of word-cities. These multiples positionalities enabled by the politics of location generate the possibilities of multiple geographies that transcend the ideology of the separate spheres.

\section{References}

Ardener, S. (1993). Ground Rules and Social Maps for Women. In S. Ardener (Ed.), Women in Space: Ground Rules and Social Maps. Oxford: Berg. 1-30

Duncan, N. (1996). Renegotiating Gender and Sexuality in Public and Private Spaces. In N. Duncan (Ed.), Bodyspace: Destabilizing Geographies of Gender and Sexuality. London: Routledge. 125-145

Grosz, E. (1994). Bodies-Cities. In Space, Time, and Perversion. New York: Routledge. 103-110

hooks, b. (1989). Choosing the Margin as a Space of Radical Openness. In Yearnings, Race, Gender, and Cultural Politics. London: Turnaround Press. 145-153

Jameson, F. (2003). Postmodernism, or the Cultural Logic of Late Capitalism. New Left Review no. 146 (JulyAugust): 59-92

Joseph, M. (2010). Serious Men. Noida: HarperCollins.

Joseph, M. (2012). The Illicit Happiness of Other People. Noida: HarperColllins.

Keith, M. and Pile, S. (1993). Introduction. In Keith, M. and Pile, S. (Eds.) Place and the Politics of Identity. London: Routledge. 1-21

Pike, B. (2011). The City as Image. In LeGates, R. and Stout, F. (Eds.) The City Reader. London: Routledge. 242-249

Pollock, G. (1988). Modernity and the Spaces of Femininity. In Vision and Difference. London: Routledge. 50-90

Rendell, J. (2000). Introduction: 'Gender, Space.' In Rendell, J., Penner, B., and Borden, I. (Eds.) Gender, Space, Architecture. London: Routledge. 101-111

Young, I. (1987). Impartiality and the Civic Public. In Benhabib, S. and Cornell, D. (Eds.) Feminism as Critique. Minneapolis: University of Minnesota Press. 56-76

Parvathi M.S. is a Research Fellow in the Department of English Literature in EFLU, Hyderabad. She specializes in Gender and Sexuality, Kerala Culture, and Contemporary Fiction. You can mail her at msparvathi1994@gmail.com. 